\title{
Pharmacokinetics and safety of dexlansoprazole $M R$ in pediatric patients with symptomatic gastroesophageal reflux disease
}

This article was published in the following Dove Press journal:

Clinical and Experimental Gastroenterology

8 December 2014

Number of times this article has been viewed

\author{
Michael Kukulka' \\ Sai Nudurupati² \\ Maria Claudia Perez ${ }^{3}$ \\ 'Department of Clinical Pharmacology, \\ ${ }^{2}$ Department of Analytical Sciences, \\ ${ }^{3}$ Department of Clinical Science, \\ Takeda Development Center \\ Americas, Inc., Deerfield, IL, USA
}

Objective: To evaluate the safety and pharmacokinetic profile of dexlansoprazole modifiedrelease (MR) capsules in pediatric patients with symptomatic gastroesophageal reflux disease (GERD).

Methods: This Phase I, open-label study enrolled male and female patients (1 to 11 years of age) with GERD. Patients received dexlansoprazole MR $15 \mathrm{mg}, 30 \mathrm{mg}$, or $60 \mathrm{mg}$ (according to weight) once daily for 7 days. Blood samples for the measurement of plasma dexlansoprazole concentrations were collected for 24 hours after the day 7 dose. Dexlansoprazole plasma concentrations and pharmacokinetic parameters were summarized by dose group. Safety assessments included adverse events (AEs), clinical laboratory evaluations, fasting gastrin concentrations, physical examinations, electrocardiograms, and vital signs.

Results: Thirty-six patients received study drug (12 per dose group), and 31 had evaluable pharmacokinetic data. There was a significant effect of weight on dose-normalized area under the curve (AUC, $P=0.003$ ) and dose-normalized maximum plasma concentration $\left(\mathrm{C}_{\max }\right)$ $(P=0.013)$, indicating that for a given dose, dexlansoprazole exposure decreases as body weight increases. After adjusting for body weight, both dexlansoprazole $\mathrm{C}_{\max }$ and $\mathrm{AUC}$ increased in an approximately dose-proportional manner with increasing dexlansoprazole dose. A total of ten of 36 patients reported at least one treatment-emergent AE, with most events considered mild in intensity. The most common AEs were vomiting, abdominal pain, diarrhea, and nausea.

Conclusion: In 1- to 11-year-old patients with symptomatic GERD, weight-adjusted dexlansoprazole AUC and $\mathrm{C}_{\max }$ increased approximately dose-proportionally. However, for a given dose, dexlansoprazole exposure decreased with increasing body weight. Dexlansoprazole MR was well tolerated, and the incidence of AEs did not increase with increasing dose.

Keywords: TAK-390MR, dual delayed release, proton pump inhibitor

\section{Introduction}

Gastroesophageal reflux disease (GERD) is a condition of multifactorial etiology resulting in the reflux of gastric contents into the esophagus through the lower esophageal sphincter. ${ }^{1}$ The prevalence of GERD increases with age, from $2.5 \%$ of children between 3 and 9 years of age to $8.5 \%$ of those between 10 and 17 years of age. ${ }^{2}$ Similarly, the overall prevalence of erosive esophagitis (EE) increases with age, from $5.5 \%$ in infants to $12.4 \%$ in children and adolescents. ${ }^{3}$ Younger children usually present with extraesophageal manifestations, regurgitation, and epigastric pain, while older children and adolescents typically present with adult-type GERD symptoms of heartburn and regurgitation. ${ }^{4,5}$ Pediatric GERD is a condition that is not always outgrown and can manifest itself as a chronic disease. ${ }^{5}$ In addition, children with GERD have a higher reported frequency of sinusitis, asthma, laryngitis, and pneumonia than
Correspondence: Michael Kukulka Takeda Development Center Americas, Inc., I Takeda Parkway, Deerfield, IL 600I5, USA

Tel +l 2245542205

Fax + I 2245547933

Email michael.kukulka@takeda.com 
children without GERD. ${ }^{6}$ The standard treatments for GERD in children are histamine type-2 receptor antagonists and proton pump inhibitors (PPIs). ${ }^{5,7-12}$

Dexlansoprazole is a PPI and is the R-enantiomer of lansoprazole. Dexlansoprazole MR (Dexilant; Takeda Pharmaceuticals America, Inc., Deerfield, IL, USA) is a modified-release (MR) formulation of dexlansoprazole, which employs an innovative Dual Delayed Release ${ }^{\mathrm{TM}}$ (DDR) delivery system, resulting in a dexlansoprazole plasma concentration-time profile with two distinct peaks: the first peak occurs 1 to 2 hours after administration, followed by a second peak within 4 to 5 hours. The DDR formulation is designed to extend the duration of drug exposure and maintain pharmacologically active levels of drug over a longer period of time.

Dexlansoprazole MR (30 mg once daily) is approved in adults in several countries, including the United States, for treatment of symptomatic nonerosive GERD and maintenance of healed EE and relief of heartburn; a dose of 60 $\mathrm{mg}$ once daily is approved for healing EE. ${ }^{13}$ The pharmacokinetic, pharmacodynamic, efficacy, and safety profiles of dexlansoprazole MR following administration of doses of $30 \mathrm{mg}, 60 \mathrm{mg}$, and $90 \mathrm{mg}$ have been extensively studied in more than 5,000 adults in completed randomized, doubleblind, controlled clinical studies. ${ }^{13,14}$ The pharmacokinetics and safety of dexlansoprazole MR have been evaluated in adolescents (12 to 17 years old), ${ }^{15}$ and the results indicated that the pharmacokinetic and safety profiles in adolescents were similar to those in adults. However, prior to the current study, the pharmacokinetics and safety of dexlansoprazole MR had not been studied in younger patients. The pharmacokinetics, efficacy, and tolerability of lansoprazole have been established in pediatric patients, aged 1 to 17 years, for short-term treatment of symptomatic GERD and EE. ${ }^{11,12,16}$

The objective of this study (ClinicalTrials.gov registration information: http://clinicaltrials.gov/ct2/show/ NCT01045096) was to evaluate the pharmacokinetics and safety of dexlansoprazole MR in pediatric patients 1 to 11 years of age with symptomatic GERD. The study was intended to generate data to assist in choosing the appropriate doses for safety and efficacy studies in the 1- to 11-year old population with nonerosive GERD and EE.

\section{Methods}

\section{Patient selection}

Male and female patients between 1 and 11 years of age, inclusive, with a physician-documented history of symptomatic GERD for at least 2 months prior to screening, were eligible for inclusion in the study. Physician-documented symptoms of GERD included vomiting/regurgitation, dysphagia, cough, abdominal pain, irritability, and/or failure to thrive or feeding refusal. Patients must have had a body weight at screening within the fifth through 95th percentile by age, as determined by the National Center for Health Statistics. ${ }^{17}$

Exclusion criteria included evidence of current cardiovascular, central nervous system, pulmonary, or endocrine disease; hepatic, hematopoietic, renal, or metabolic dysfunction; serious allergy, asthma, or allergic skin rash; hypersensitivity to PPIs or components of dexlansoprazole MR; history of malignant disease or human immunodeficiency virus (HIV) infection; or positive test result for hepatitis B surface antigen or hepatitis C virus antibody. Dexlansoprazole is metabolized in part by cytochrome $\mathrm{P} 450$ 2C19 (CYP2C19). ${ }^{13}$ Increases in dexlansoprazole exposure have been observed in patients who are determined to be CYP2C19 poor metabolizers. Therefore, patients were tested for CYP2C19 metabolizer status at screening and poor metabolizers were excluded from the study. Patients discontinued the use of all prescription and nonprescription medications, vitamins, dietary supplements, and grapefruit juice, from 10 days prior to day 1 and for the duration of the study. Herbal over-the-counter medications were not allowed for 28 days prior to day 1 and for the duration of the study. Prescription or nonprescription PPIs, histamine-2 receptor antagonists, sucralfate, and antacids on a regular basis were discontinued on day -1 (except for cimetedine, which was discontinued on day -10) and for the duration of the study.

\section{Study design}

This Phase I, open-label study was conducted at three study sites (see Acknowledgments) in the United States between March 2010 and February 2011. The study was conducted in accordance with the Declaration of Helsinki, ${ }^{18}$ the International Conference on Harmonisation Harmonised Tripartite Guideline for Good Clinical Practice, ${ }^{19}$ and all applicable local regulations. The study protocol was approved by the Institutional Research Board at each participating site. Prior to the initiation of any study procedures, written informed consent was obtained from the patient's parent or legal guardian, and assent (if applicable) was provided by the patient.

The study comprised a screening period of up to 28 days and a 7-day treatment period, including a 2-day in-clinic pharmacokinetic sampling period. Following the screening visit, patients who met all the inclusion and none of the exclusion criteria returned to the study site on day -1 for baseline evaluations that included a complete physical examination 
with vital signs, clinical laboratory tests, screening for hepatitis, illicit drugs of abuse and alcohol, and recording of adverse events and concomitant medications.

Eligible patients were assigned to one of three dose groups according to their baseline weight. The dosing scheme for this study was designed so that no pediatric patient received a dexlansoprazole dose, on a $\mathrm{mg} / \mathrm{kg}$ basis, that was higher than the highest $\mathrm{mg} / \mathrm{kg}$ dose received by adult patients in the dexlansoprazole Phase III studies. Patients weighing $\geq 8.6$ to $<12.7 \mathrm{~kg}$ received dexlansoprazole MR $15 \mathrm{mg}$; patients weighing $\geq 12.7$ to $<25.4 \mathrm{~kg}$ were randomly assigned in a 1:1 ratio to receive dexlansoprazole MR $15 \mathrm{mg}$ or $30 \mathrm{mg}$; and patients weighing $\geq 25.4 \mathrm{~kg}$ were randomly assigned in a 1:2 ratio to receive dexlansoprazole MR $30 \mathrm{mg}$ or $60 \mathrm{mg}$. The randomization schedule was generated by Takeda Development Center Americas, Inc., before the start of the study and provided to the respective study sites.

Following the completion of all day -1 testing, study drug and a treatment diary were provided to the patient's parent or caregiver, who administered study drug on days 1 to 6 at home following an overnight fast (if tolerated). One capsule of study drug was administered each day, prior to breakfast, with water or by sprinkling the contents of the capsule on 1 tablespoon of applesauce. Patients returned to the study site on day 7 , and study drug was administered by study personnel after patients had been fasting for at least 30 minutes. Patients remained at the study site until the final study procedures had been completed on day 8 .

\section{Pharmacokinetic evaluation}

Blood samples for the measurement of dexlansoprazole plasma concentrations were collected on day 7 prior to dosing and at $0.5,1,1.5,2,3,4,5,6,7,8,10,12$, and 24 hours after dosing. Blood samples were collected into chilled evacuated tubes containing dipotassium ethylenediaminetetraacetic acid and centrifuged at $4^{\circ} \mathrm{C}$ to separate the plasma from the cells. Plasma samples were stored at $-20^{\circ} \mathrm{C}$ until analysis. Dexlansoprazole plasma concentrations were measured by a proprietary liquid chromatography tandem mass spectrometry assay, with a validated concentration range of 2.00 to $2,000 \mathrm{ng} / \mathrm{mL}$ at PPD, Inc. (Middleton, WI, USA). The stability of dexlansoprazole during the processing and storage of the samples was established during assay validation at PPD. Dexlansoprazole concentrations were tabulated, and concentrations below the lower limit of quantitation were set to zero for pharmacokinetic analysis and summary statistics. The following dexlansoprazole pharmacokinetic parameters were calculated for each patient: area under the concentration-time curve from time 0 to time of last quantifiable concentration $\left(\mathrm{AUC}_{\mathrm{t}}\right)$, area under the concentration-time curve from time 0 to 24 hours postdose $\left(\mathrm{AUC}_{24}\right)$, maximum plasma concentration $\left(\mathrm{C}_{\max }\right)$, time to $\mathrm{C}_{\max }\left[\mathrm{t}_{\max }\right]$, terminal elimination half-life $\left[\mathrm{t}_{1 / 2 \mathrm{z}}\right]$, and oral clearance $[\mathrm{CL} / \mathrm{F}]$. In addition, dose-normalized $\mathrm{C}_{\max }$, $\mathrm{AUC}_{\mathrm{t}}$, and $\mathrm{AUC}_{24}$ values were calculated by dividing the appropriate parameter by the administered dose.

\section{Safety evaluations}

Safety variables included adverse events (AEs), clinical laboratory tests (serum chemistry, hematology, and urinalysis), fasting gastrin concentrations, vital signs, physical examinations, and electrocardiograms (ECGs). A treatment-emergent AE (TEAE) was defined as an AE that started or worsened any time after the first dose of study drug until 30 days after the last dose of study drug. Adverse events were recorded in the treatment diary by the patient's parent or caregiver on days 1 to 6 and assessed by the Investigator on days 7 and 8 . AEs were characterized as mild (transient and easily tolerated), moderate (caused discomfort and interrupted usual activities), or severe (caused considerable interference with usual activities).

\section{Statistical analyses}

A sample size of 36 patients (12 per dose group) was planned for this study. The number of patients and the intense pharmacokinetic sampling for each patient was expected to provide sufficient information for the characterization of the pharmacokinetic profile of dexlansoprazole MR $15 \mathrm{mg}$, $30 \mathrm{mg}$, and $60 \mathrm{mg}$ in this population. All data analyses were performed using SAS ${ }^{\circledR}$ Version 9.1 (SAS Institute, Cary, NC, USA). All statistical tests were two-tailed at $\alpha=0.05$ level for significance.

\section{Pharmacokinetic analyses}

Pharmacokinetic analyses included all patients with at least one estimable dexlansoprazole pharmacokinetic parameter on day 7. Dexlansoprazole pharmacokinetic parameters were determined from the plasma concentration-time profiles for all dose groups on day 7, using actual, rather than scheduled, sampling times. Pharmacokinetic parameters were derived using noncompartmental methods, with WinNonlin ${ }^{\circledR}$ Enterprise Version 5.2 (Pharsight Corp, St Louis, MO, USA). Pharmacokinetic parameters were summarized using descriptive statistics for each dose group. In addition, pharmacokinetic parameters were summarized by patient body weight and age groups. 
Analysis of covariance (ANCOVA) models, with baseline weight as a continuous factor and dose group as a fixed factor, were used for $\mathrm{t}_{\max }$ and the natural logarithm of dosenormalized $\mathrm{C}_{\max }$ and AUC. Pairwise comparisons between dose groups were conducted. Dose proportionality was assessed using the ratios of dose-normalized $\mathrm{C}_{\max }$ and $\mathrm{AUC}$ central values.

\section{Safety analyses}

Safety analyses included all patients who received at least one dose of study drug. All safety assessments (TEAEs, clinical laboratory evaluations, vital signs, and ECGs) were summarized by dose group, using descriptive statistics. The results of the physical examinations were listed by dose group.

\section{Results}

\section{Study population}

A total of 45 patients were screened for enrollment, and 36 patients ( 24 male, 12 female) received study drug ( 12 in each dose group). There were five patients in the lowest weight group ( $\geq 8.6$ to $<12.7 \mathrm{~kg}$ ), 13 in the middle weight group ( $\geq 12.7$ to $<25.4 \mathrm{~kg}$ ), and 18 in the highest weight group ( $\geq 25.4 \mathrm{~kg}$ ). All 36 patients were included in the safety analyses, and
31 patients were included in the pharmacokinetic analyses. Of the five patients excluded from the pharmacokinetic analyses, three patients voluntarily withdrew prior to study completion (one withdrawn by the patient's mother, one refused an indwelling catheter, and one had no accessible venous access), and two patients had pharmacokinetic parameters not calculable due to samples that were missing or not collected.

The mean age of all patients was 7.1 years (range, $1-11$ years); $67 \%$ of patients were male, $89 \%$ were White, and $61 \%$ were Hispanic or Latino. Since the dose administered was based on body weight, the mean weight, height, and body mass index varied by dose group (Table 1).

\section{Pharmacokinetic evaluation}

Following daily administration of dexlansoprazole MR $15 \mathrm{mg}$, $30 \mathrm{mg}$, or $60 \mathrm{mg}$ for 7 days, the dexlansoprazole plasma concentration-time profiles were generally reflective of the extended-release characteristics of the two granule types contained in the dexlansoprazole MR capsule (Figure 1).

Mean $\mathrm{C}_{\max }$ values increased when dexlansoprazole doses increased from $15 \mathrm{mg}$ to $30 \mathrm{mg}$ but were similar for the $30 \mathrm{mg}$ and $60 \mathrm{mg}$ doses. The mean $\mathrm{AUC}_{\mathrm{t}}$ and $\mathrm{AUC}_{24}$ values increased with dose. Median $\mathrm{t}_{\max }$ values were 3.0 to 4.0 hours

Table I Patient demographics and other baseline characteristics

\begin{tabular}{|c|c|c|c|c|}
\hline & $\begin{array}{l}\text { Dexlansoprazole } \\
\text { MR I5 mg } \\
n=12\end{array}$ & $\begin{array}{l}\text { Dexlansoprazole } \\
\text { MR } 30 \mathrm{mg} \\
\mathrm{n}=12\end{array}$ & $\begin{array}{l}\text { Dexlansoprazole } \\
\text { MR } 60 \mathrm{mg} \\
\mathrm{n}=12\end{array}$ & $\begin{array}{l}\text { Overall } \\
N=36\end{array}$ \\
\hline \multicolumn{5}{|l|}{ Sex, n (\%) } \\
\hline Male & $7(58.3)$ & $10(83.3)$ & $7(58.3)$ & $24(66.7)$ \\
\hline Female & $5(4 I .7)$ & $2(16.7)$ & $5(4 I .7)$ & $12(33.3)$ \\
\hline \multicolumn{5}{|l|}{ Age, years } \\
\hline Mean (SD) & $3.3(1.97)$ & $7.8(2.89)$ & $10.2(0.72)$ & $7.1(3.50)$ \\
\hline \multicolumn{5}{|l|}{ Ethnicity, n (\%) } \\
\hline Hispanic or Latino & $6(50.0)$ & $8(66.7)$ & $8(66.7)$ & $22(66.1)$ \\
\hline Not Hispanic or Latino & $6(50.0)$ & $4(33.3)$ & $4(33.3)$ & 14 (38.9) \\
\hline \multicolumn{5}{|l|}{ Race, n (\%) } \\
\hline Black or African American & $2(16.7)$ & 0 & 0 & $2(5.6)$ \\
\hline White & $8(66.7)$ & $12(100)$ & $12(100)$ & $32(88.9)$ \\
\hline Multiracial & $2(16.7)$ & 0 & 0 & $2(5.6)$ \\
\hline Mean height (SD), cm & $97.4(17.01)$ & $131.9(\mid 8.80)$ & I46.3 (8.73) & $125.2(25.69)$ \\
\hline Overall mean weight (SD), kg & I $5.7(5.43)$ & $29.7(11.86)$ & $41.0(8.50)$ & $28.8(13.64)$ \\
\hline$\geq 8.6$ to $<12.7 \mathrm{~kg}$ & II.I (I.05) & 0 & 0 & II.I (I.05) \\
\hline$\geq 12.7$ to $<25.4 \mathrm{~kg}$ & $19.0(4.76)$ & $20.3(3.67)$ & 0 & $19.6(4.17)$ \\
\hline$\geq 25.4 \mathrm{~kg}$ & 0 & $39.1(9.19)$ & $41.0(8.50)$ & $40.3(8.5 I)$ \\
\hline \multirow{2}{*}{\multicolumn{5}{|c|}{$\begin{array}{l}\text { Number of patients per dose } \\
\text { by baseline weight group }\end{array}$}} \\
\hline & & & & \\
\hline$\geq 8.6$ to $<12.7 \mathrm{~kg}$ & 5 & 0 & 0 & 5 \\
\hline$\geq 12.7$ to $<25.4 \mathrm{~kg}$ & 7 & 6 & 0 & 13 \\
\hline$\geq 25.4 \mathrm{~kg}$ & 0 & 6 & 12 & 18 \\
\hline Mean BMI (SD), kg/m² & I6.3 (I.82) & I6.4 (3.09) & $19.0(2.56)$ & $17.2(2.77)$ \\
\hline
\end{tabular}

Abbreviations: BMI, body mass index; SD, standard deviation; MR, modified release. 


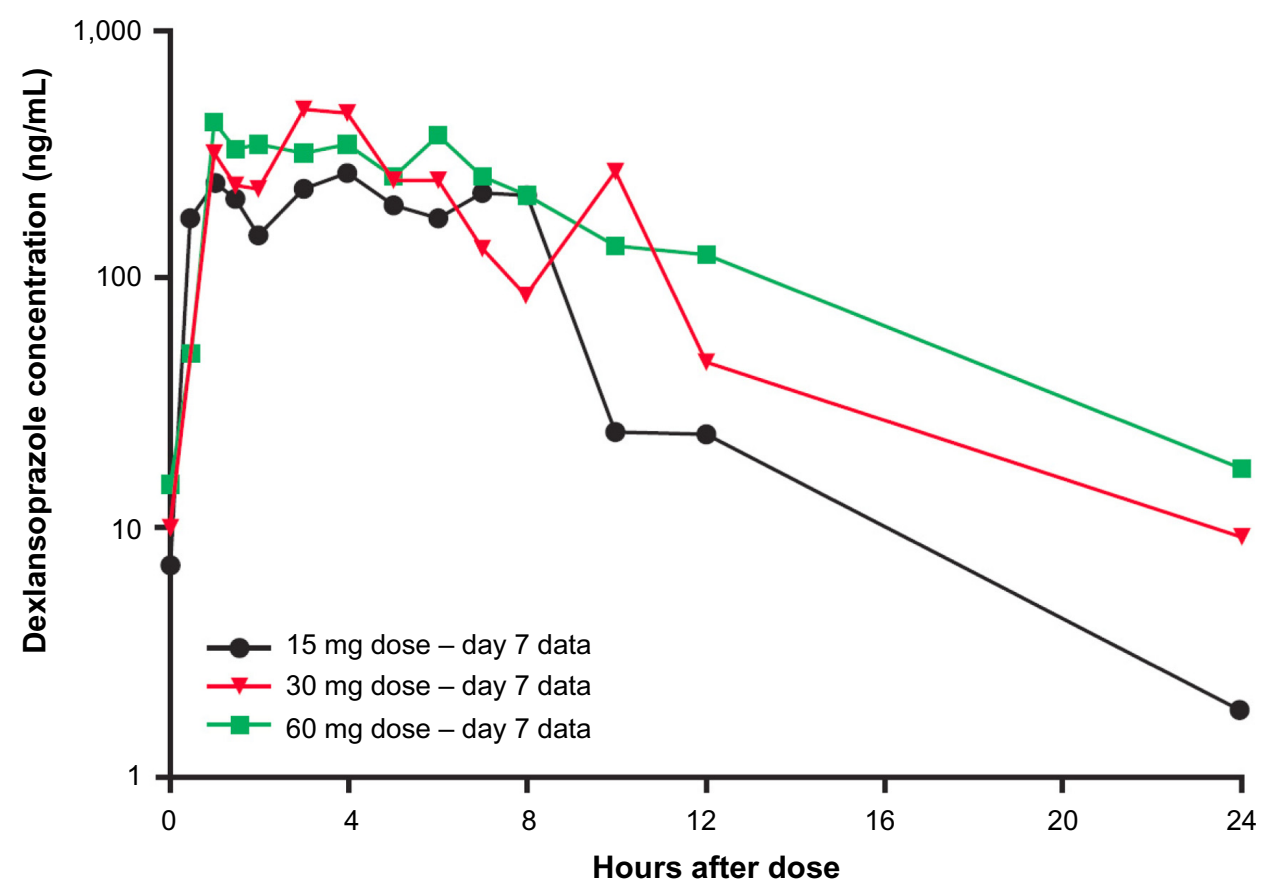

Figure I Mean dexlansoprazole plasma concentration-time profiles (log-linear format) on day 7, following once-daily administration of I $5 \mathrm{mg}$, $30 \mathrm{mg}$, or $60 \mathrm{mg}$ dexlansoprazole MR capsules for 7 days, to pediatric patients I to II years of age with GERD.

Abbreviations: GERD, gastroesophageal reflux disease; MR, modified release.

(range, 0.5-12.0 hours) for all dose groups (Table 2). The descriptive statistics for $\mathrm{AUC}_{24}, \mathrm{t}_{1 / 2 \mathrm{z}}$, and CL/F are presented in Table 2. However, the number of patients for whom $\mathrm{AUC}_{24}$, $t_{1 / 2 z}$, and $C L / F$ values were estimable was lower than for the other parameters because the terminal elimination rate constant (used in the calculation of these parameters) could not be estimated for all patients, due to the variability in plasma concentrations during the elimination portion of the plasma concentration-time profiles. The data are included for completeness, but only limited conclusions can be drawn from these data.

When summarized by dose group, the mean AUC values increased in a less than dose-proportional manner when dose was increased from $30 \mathrm{mg}$ to $60 \mathrm{mg}$. Because the dose assignment was based on body weight per the study design, additional descriptive statistics were calculated to describe the dexlansoprazole AUC values separately for lighter and heavier patients. The AUC values for the $15 \mathrm{mg}, 30 \mathrm{mg}$, and $60 \mathrm{mg}$ doses in children were summarized by body weight (Table 3) and age (Table 4) groups.

The data suggest that within the weight categories of $\leq 30 \mathrm{~kg}$ or $>30 \mathrm{~kg}$ (Table 3), exposure increased with increasing dose, and the increases were reasonably dose proportional. For the patients in the $\leq 30 \mathrm{~kg}$ weight category, the mean AUC values for $30 \mathrm{mg}$ and $60 \mathrm{mg}$ doses were generally similar to the adolescent and adult AUCs for the respective doses. ${ }^{13,15,20}$ However, in patients $>30 \mathrm{~kg}$, mean exposures were lower than adolescent and adult exposures, at both the $30 \mathrm{mg}$ and $60 \mathrm{mg}$ doses.

When summarized by age group (Table 4), a similar trend was apparent. The mean AUC values for the $30 \mathrm{mg}$ dose in patients between 1 and 6 years old were generally similar to those observed in the adolescents and adults. ${ }^{13,15,20}$ No patient younger than 7 years old received the $60 \mathrm{mg}$ dose. For patients between 7 and 11 years old, the mean dexlansoprazole exposures were lower than adolescent and adult exposures at both the $30 \mathrm{mg}$ and $60 \mathrm{mg}$ doses.

Table 5 provides the AUC values summarized by both age and weight groups. The summary of the data suggests that body weight, rather than age, is the more important factor when assessing the exposure differences in this population. For patients 1 to 6 years old and 7 to 11 years old who weighed $\leq 30$ $\mathrm{kg}$, the mean AUCs from the $30 \mathrm{mg}$ dose were similar to those for adolescents and adults. ${ }^{13,15,20}$ For patients between 7 and 11 years old who weighed $\leq 30 \mathrm{~kg}$ and received the $60 \mathrm{mg}$ dose, the mean AUCs are also similar to those for adolescents and adults. For patients between 7 and 11 years old who weighed $>30 \mathrm{~kg}$, the mean AUCs from the $30 \mathrm{mg}$ and $60 \mathrm{mg}$ doses are approximately half of those for adolescents and adults.

An ANCOVA with dose group as a fixed factor and baseline weight as a continuous covariate showed a significant effect of weight on dose-normalized, log-transformed 
Table 2 Dexlansoprazole pharmacokinetic parameters for patients I to II years old, following 7 days of once-daily dosing with I5 mg, $30 \mathrm{mg}$, or $60 \mathrm{mg}$ dexlansoprazole MR capsules

\begin{tabular}{|c|c|c|c|c|c|c|}
\hline Parameter & $\begin{array}{l}\mathbf{t}_{\max } \\
(\mathrm{hr})\end{array}$ & $\begin{array}{l}C_{\max } \\
(\mathrm{ng} / \mathrm{mL})\end{array}$ & $\begin{array}{l}\text { AUC }_{\mathrm{t}} \\
(\mathrm{ng} \cdot \mathrm{hr} / \mathrm{mL})\end{array}$ & $\begin{array}{l}\text { AUC }_{24} \\
(\mathrm{ng} \cdot \mathrm{hr} / \mathrm{mL})\end{array}$ & $\begin{array}{l}t_{1 / 2 z} \\
(h r)\end{array}$ & $\begin{array}{l}\text { CL/F } \\
\text { (L/hr) }\end{array}$ \\
\hline \multicolumn{7}{|c|}{ Dexlansoprazole MR } \\
\hline \multicolumn{7}{|l|}{$15 \mathrm{mg}$ dose } \\
\hline $\mathrm{N}$ & 9 & 9 & 9 & 6 & 6 & 6 \\
\hline Mean & 4.39 & 559 & 1,914 & 2,149 & 0.85 & 7.51 \\
\hline SD & 3.182 & 225.3 & 631.8 & 563.7 & 0.291 & 2.505 \\
\hline Min & 0.48 & 235 & 993 & 1,217 & 0.49 & 5.12 \\
\hline Median & 4.00 & 482 & 2,029 & 2,146 & 0.81 & 7.01 \\
\hline $\operatorname{Max}$ & 8.05 & 887 & 2,918 & 2,931 & 1.38 & 12.33 \\
\hline \multicolumn{7}{|c|}{ Dexlansoprazole MR } \\
\hline \multicolumn{7}{|l|}{$30 \mathrm{mg}$ dose } \\
\hline$N$ & 11 & 11 & 11 & 8 & 8 & 8 \\
\hline Mean & 4.09 & $\mathrm{I}, 005$ & 2,892 & 2,628 & 1.26 & 16.16 \\
\hline SD & 2.342 & 748.1 & $1,668.6$ & $1,383.2$ & 0.841 & 11.443 \\
\hline Min & 1.00 & 142 & 757 & 763 & 0.59 & 6.89 \\
\hline Median & 3.03 & 874 & 2,958 & 2,705 & 0.94 & 11.25 \\
\hline Max & 10.00 & 2,690 & 6,391 & 4,357 & 3.10 & 39.30 \\
\hline \multicolumn{7}{|c|}{ Dexlansoprazole MR } \\
\hline \multicolumn{7}{|l|}{$60 \mathrm{mg}$ dose } \\
\hline $\mathrm{N}$ & II & II & II & 6 & 6 & 6 \\
\hline Mean & 4.09 & 964 & 3,747 & 3,330 & 2.75 & 26.93 \\
\hline SD & 3.590 & 519.0 & $2,795.6$ & $\mathrm{I}, 883.3$ & 2.654 & 21.168 \\
\hline Min & 1.00 & 193 & 925 & 931 & 0.92 & 9.81 \\
\hline Median & 3.00 & 1,050 & 3,448 & 3,685 & 1.77 & 16.35 \\
\hline Max & 12.00 & 1,660 & 10,568 & 6,119 & 7.81 & 64.47 \\
\hline
\end{tabular}

Abbreviations: $A \cup C_{r}$, area under the plasma concentration-time curve from time 0 to the time of the last quantifiable concentration; $\mathrm{AUC}_{24}$, area under the plasma concentration-time curve from time 0 to 24 hours postdose; $C_{\text {max }}$, maximum concentration; CL/F, oral clearance; Max, maximum; Min, minimum; MR, modified release; SD, standard deviation; $\mathrm{t}_{1 / 22}$, terminal elimination half-life; $\mathrm{t}_{\max }$, time to maximum concentration.

Table 3 Summary of dexlansoprazole exposure analyzed based on body weight group

\begin{tabular}{|c|c|c|c|c|c|}
\hline Dose (N) & $\begin{array}{l}\text { Mean age } \\
\text { (years) }\end{array}$ & $\begin{array}{l}\text { Mean weight } \\
\text { (kg) }\end{array}$ & $\begin{array}{l}\text { Mean AUC } \\
(\mathrm{ng} \cdot \mathrm{hr} / \mathrm{mL})\end{array}$ & $\begin{array}{l}\text { Adolescent AUC } \\
(\mathrm{ng} \cdot \mathrm{hr} / \mathrm{mL})\end{array}$ & $\begin{array}{l}\text { Adult AUC } \\
(\mathrm{ng} \cdot \mathrm{hr} / \mathrm{mL})\end{array}$ \\
\hline \multicolumn{6}{|c|}{ Children I-II years } \\
\hline \multicolumn{6}{|l|}{ old: $\leq 30 \mathrm{~kg}$} \\
\hline $15 \mathrm{mg}(9)$ & 3.1 & 14.6 & 1,914 & Not available & Not available \\
\hline $30 \mathrm{mg}(8)$ & 6.5 & 22.2 & 3,367 & $2,886^{15}$ & $3,275^{13,20}$ \\
\hline $60 \mathrm{mg}(2)$ & 9.5 & 27.5 & 5,020 & $5,120^{15}$ & $6,529^{13,20}$ \\
\hline \multicolumn{6}{|c|}{ Children I-II years } \\
\hline \multicolumn{6}{|l|}{ old: >30 kg } \\
\hline 30 mg (3) & 10.3 & 43.4 & 1,625 & $2,886^{15}$ & $3,275^{13,20}$ \\
\hline $60 \mathrm{mg}$ (9) & 10.3 & 44.8 & 3,464 & $5,120^{15}$ & $6,529^{13,20}$ \\
\hline
\end{tabular}

Abbreviation: AUC, area under the plasma concentration-time curve.

Table 4 Summary of dexlansoprazole exposure analyzed based on age group

\begin{tabular}{|c|c|c|c|c|c|}
\hline Dose (N) & $\begin{array}{l}\text { Mean age } \\
\text { (years) }\end{array}$ & $\begin{array}{l}\text { Mean weight } \\
(\mathrm{kg})\end{array}$ & $\begin{array}{l}\text { Mean AUC } \\
(\mathrm{ng} \cdot \mathrm{hr} / \mathrm{mL})\end{array}$ & $\begin{array}{l}\text { Adolescent AUC } \\
(\mathrm{ng} \cdot \mathrm{hr} / \mathrm{mL})\end{array}$ & $\begin{array}{l}\text { Adult AUC } \\
(\mathrm{ng} \cdot \mathrm{hr} / \mathrm{mL})\end{array}$ \\
\hline \multicolumn{6}{|c|}{ Children I to 6 years old } \\
\hline 15 mg (9) & 3.1 & 14.6 & 1,914 & Not available & Not available \\
\hline 30 mg (5) & 4.8 & 19.6 & 3,639 & $2,886^{15}$ & $3,275^{13,20}$ \\
\hline \multicolumn{6}{|c|}{ Children 7 to II years old } \\
\hline 30 mg (6) & 9.8 & 35.0 & 2,270 & $2,886^{15}$ & $3,275^{13,20}$ \\
\hline 60 mg (II) & 10.2 & 41.7 & 3,747 & $5,120^{15}$ & $6,529^{13,20}$ \\
\hline
\end{tabular}

Abbreviation: AUC, area under the plasma concentration-time curve. 
Table 5 Summary of dexlansoprazole exposure analyzed based on age and weight groups

\begin{tabular}{|c|c|c|c|c|c|}
\hline Dose (N) & $\begin{array}{l}\text { Mean age } \\
\text { (years) }\end{array}$ & $\begin{array}{l}\text { Mean weight } \\
(\mathrm{kg})\end{array}$ & $\begin{array}{l}\text { Mean AUC } \\
\text { (ng } \cdot h r / m L)\end{array}$ & $\begin{array}{l}\text { Adolescent AUC } \\
(\mathrm{ng} \cdot \mathrm{hr} / \mathrm{mL})\end{array}$ & $\begin{array}{l}\text { Adult AUC } \\
(\mathrm{ng} \cdot \mathrm{hr} / \mathrm{mL})\end{array}$ \\
\hline \multicolumn{6}{|c|}{$\begin{array}{l}\text { Children I to } 6 \text { years old, } \\
\text { weight } \leq 30 \mathrm{~kg}\end{array}$} \\
\hline 15 mg (9) & 3.1 & 14.6 & $1,9 \mid 4$ & Not available & Not available \\
\hline 30 mg (5) & 4.8 & 19.6 & 3,639 & $2,886^{15}$ & $3,275^{13,20}$ \\
\hline \multicolumn{6}{|c|}{$\begin{array}{l}\text { Children } 7 \text { to II years old, } \\
\text { weight } \leq 30 \mathrm{~kg}\end{array}$} \\
\hline 30 mg (3) & 9.3 & 26.5 & $2,9 \mid 4$ & $2,886^{15}$ & $3,275^{13,20}$ \\
\hline $60 \mathrm{mg}(2)$ & 9.5 & 27.5 & 5,020 & $5,120^{15}$ & $6,529^{13,20}$ \\
\hline \multicolumn{6}{|c|}{$\begin{array}{l}\text { Children } 7 \text { to II years old, } \\
\text { weight }>30 \mathrm{~kg}\end{array}$} \\
\hline 30 mg (3) & 10.3 & 43.4 & 1,625 & $2,886^{15}$ & $3,275^{13,20}$ \\
\hline 60 mg (9) & 10.3 & 44.8 & 3,464 & $5,120^{15}$ & $6,529^{13,20}$ \\
\hline
\end{tabular}

Abbreviation: AUC, area under the plasma concentration-time curve.

$\operatorname{AUC}(P=0.003)$ and dose-normalized, log-transformed $\mathrm{C}_{\text {max }}$ $(P=0.013)$, indicating that for a given dose, dexlansoprazole exposure decreases as body weight increases (Table 6). The point estimates for the ratios of the central values for dosenormalized $\mathrm{C}_{\max }$ and $\mathrm{AUC}$ indicated that after adjusting for body weight, dexlansoprazole $\mathrm{AUC}$ and $\mathrm{C}_{\max }$ increased in an approximately dose-proportional manner for $15 \mathrm{mg}, 30 \mathrm{mg}$, and $60 \mathrm{mg}$ doses (Table 7).

\section{Safety results}

A total of ten patients (28\%) experienced at least one TEAE during the study, and three patients $(8 \%)$ had at least one TEAE considered related to study drug. The incidence of TEAEs did not increase with higher dexlansoprazole doses, and most events were mild in intensity. The most commonly reported TEAEs were vomiting, abdominal pain, diarrhea, and nausea (Table 8). One patient (60 mg dose group) had a serious TEAE, of moderate vomiting, on day 7 , which resulted in hospitalization. This event, which was resolved on day 8 , was considered by the Investigator to be not related to study

Table 6 ANCOVA for dexlansoprazole dose-normalized AUC and $C_{\max }$ following once-daily $15 \mathrm{mg}, 30 \mathrm{mg}$, or $60 \mathrm{mg}$ dexlansoprazole MR capsules for 7 days to patients I to II years of age with GERD

\begin{tabular}{lll}
\hline Parameter & Factor & $P$-value \\
\hline Dose-normalized AUC & Dose & 0.910 \\
& Weight & $0.003^{* *}$ \\
Dose-normalized $C_{\max }$ & Dose & 0.820 \\
& Weight & $0.013^{*}$ \\
\hline
\end{tabular}

Note: *, ** indicate statistical significance at the 0.05 or 0.0 I level, respectively. Abbreviations: ANCOVA, analysis of covariance; AUC, area under the plasma concentration-time curve from time 0 to time of last quantifiable concentration; $\mathrm{C}_{\max }$, maximum concentration; GERD, gastroesophageal reflux disease; $\mathrm{MR}$, modified release; AUC, area under the plasma concentration-time curve. drug but related to study procedures (vasovagal response to intravenous catheter insertion for pharmacokinetic blood draws). One patient was voluntarily withdrawn from the study by her mother following mild TEAEs of hematochezia and concurrent vomiting on day 3 ; both events were considered unrelated to study drug and were resolved after approximately 1 hour. There were no clinically significant changes in clinical laboratory values, physical examination findings, vital signs, or ECGs during the study. Mean (minimum, maximum) gastrin concentrations at baseline and at day 8/early termination, summarized across regimens, were $76.9(11.0,689) \mathrm{pg} / \mathrm{mL}$ and $128(24.0,311) \mathrm{pg} / \mathrm{mL}$, respectively. The mean gastrin concentration increases from baseline to day $8 /$ early termination were $15.1 \mathrm{pg} / \mathrm{mL}, 38.1 \mathrm{pg} / \mathrm{mL}$, and $93.0 \mathrm{pg} / \mathrm{mL}$ in the $15 \mathrm{mg}, 30 \mathrm{mg}$, and $60 \mathrm{mg}$ groups, respectively.

\section{Discussion}

Dexlansoprazole MR was developed as a new therapy for treating acid-related disorders, including management

Table 7 Assessment of dose proportionality for dexlansoprazole dose-normalized $A \cup C$ and $C_{\max }$, following once-daily $15 \mathrm{mg}, 30 \mathrm{mg}$, or $60 \mathrm{mg}$ dexlansoprazole MR capsules for 7 days to patients I to I I years of age with GERD, after adjustment for baseline weight

\begin{tabular}{llll}
\hline Parameter & $\begin{array}{l}\text { Test } \\
\text { dose } \mathbf{( m g )}\end{array}$ & $\begin{array}{l}\text { Reference } \\
\text { dose } \mathbf{( m g )}\end{array}$ & $\begin{array}{l}\text { Point } \\
\text { estimate }\end{array}$ \\
\hline Dose-normalized AUC & 30 & 15 & 1.13 \\
& 60 & 15 & 1.15 \\
Dose-normalized $C_{\max }$ & 60 & 30 & 1.02 \\
& 60 & 15 & 1.20 \\
& 60 & 15 & 1.06 \\
\hline
\end{tabular}

Abbreviations: $A \cup C_{t}$, area under the plasma concentration-time curve from time 0 to time of last quantifiable concentration; $C_{\text {max }}$, maximum concentration; MR, modified release; GERD, gastroesophageal reflux disease; AUC, area under the plasma concentration-time curve. 
Table 8 Treatment-emergent adverse events

\begin{tabular}{|c|c|c|c|c|}
\hline & $\begin{array}{l}\text { Dexlansoprazole } \\
\text { MR I } 5 \mathrm{mg} \\
\mathrm{n}=12\end{array}$ & $\begin{array}{l}\text { Dexlansoprazole } \\
\text { MR } 30 \mathrm{mg} \\
\mathrm{n}=12\end{array}$ & $\begin{array}{l}\text { Dexlansoprazole } \\
\text { MR } 60 \mathrm{mg} \\
\mathrm{n}=12\end{array}$ & $\begin{array}{l}\text { Overall } \\
n=36\end{array}$ \\
\hline Any TEAE & $5(4 I .7)$ & $2(16.7)$ & $3(25.0)$ & $10(27.8)$ \\
\hline Vomiting & I (8.3) & I (8.3) & $2(16.7)$ & $4(11.1)$ \\
\hline Abdominal pain & I (8.3) & I (8.3) & I (8.3) & $3(8.3)$ \\
\hline Diarrhea & 0 & $2(16.7)$ & I (8.3) & $3(8.3)$ \\
\hline Nausea & 0 & 0 & $2(16.7)$ & $2(5.6)$ \\
\hline
\end{tabular}

Notes: Includes events reported for at least two patients overall. Data are number (\%) of patients.

Abbreviations: TEAE, treatment-emergent adverse event; MR, modified release.

of symptomatic nonerosive GERD, healing of EE, and maintenance of healed EE. The pharmacokinetics, pharmacodynamics, and safety of dexlansoprazole MR have been extensively studied in adults, ${ }^{14,20,21}$ and the safety and pharmacokinetic profiles of dexlansoprazole MR in adolescents (12-17 years) have been shown to be similar to those in adults. ${ }^{15}$ Other PPIs have been shown to be effective treatments for GERD in children more than 1 year of age, ${ }^{5,7-12}$ and it was therefore anticipated that dexlansoprazole MR could be an effective treatment for GERD in pediatric patients.

The objective of this study was to assess the pharmacokinetics and safety of dexlansoprazole in patients 1 to 11 years of age with symptomatic GERD and to identify the dexlansoprazole MR doses that would provide systemic drug exposures within the range of AUC values observed, for adults, with $30 \mathrm{mg}$ and $60 \mathrm{mg}$. These approved adult doses provide a significant increase in intragastric $\mathrm{pH},{ }^{20}$ and thus a similar exposure in pediatric patients would be expected to provide similar increases in intragastric $\mathrm{pH}$.

In this study in pediatric patients, there was a significant effect of weight on dose-normalized AUC and $\mathrm{C}_{\max }$, indicating that for a given dose, dexlansoprazole exposure decreases as body weight increases. After adjusting for this weight effect, dexlansoprazole $\mathrm{AUC}$ and $\mathrm{C}_{\max }$ increased in an approximately dose-proportional manner across the $15 \mathrm{mg}$, $30 \mathrm{mg}$, and $60 \mathrm{mg}$ doses.

The individual AUC values observed in the current study were plotted by body weight (Figure 2A) and by dose (Figure 2B) and were compared with the mean AUC values observed for $30 \mathrm{mg}$ and $60 \mathrm{mg}$ doses in healthy adults. ${ }^{13} \mathrm{In}$ addition, the mean dexlansoprazole AUC data from the current study were presented by age and weight groups, and were compared with the mean dexlansoprazole AUC data from adolescents and adults (Table 5). ${ }^{13,15,20}$ The analysis of AUC values based on body weight suggests that administration of $30 \mathrm{mg}$ and $60 \mathrm{mg}$ to children who weigh $\leq 30 \mathrm{~kg}$ would provide plasma exposure similar to adults, while these doses in children $>30 \mathrm{~kg}$ would provide exposures less than those observed in adults at the same dose level. Administration of the $15 \mathrm{mg}$ dose consistently provided AUC values that were lower than the adult $30 \mathrm{mg}$ AUC value.

The literature suggests that children may require higher doses of some PPIs in order to attain plasma exposure (AUC) similar to adults. ${ }^{5,22}$ The literature also suggests that with regard to PPIs, the pharmacodynamic response is related to AUC, $, 23,24$ and the exposure-response model for dexlansoprazole indicates that in adults, the increasing AUC exposures following administration of dexlansoprazole MR doses up to $90 \mathrm{mg}$ results in an increase in pharmacodynamic response. ${ }^{20}$ The pharmacodynamic response to dexlansoprazole was not assessed in the current study. However, dexlansoprazole is the R-enantiomer of lansoprazole, which has been studied in children and adolescents ${ }^{11,12,16,25}$ and which is approved for the short-term treatment of symptomatic GERD and EE in patients aged 1 to 17 years. ${ }^{26}$ Lansoprazole is administered as a racemic mixture of the $\mathrm{R}$ - and $\mathrm{S}$-enantiomers and displays enantiomer-specific pharmacokinetics. The S-enantiomer is rapidly cleared from the plasma, and over $85 \%$ of the plasma exposure observed following administration of lansoprazole is due to the R-enantiomer, dexlansoprazole. The pharmacokinetic and pharmacodynamic profiles of lansoprazole in the pediatric population are similar to those observed in adults. In pediatric patients, lansoprazole significantly increased the mean 24-hour $\mathrm{pH}$ and percent time $\mathrm{pH}>4 .{ }^{16}$

By inserting the mean dexlansoprazole $\mathrm{AUC}_{\mathrm{t}}$ values observed for the 30 and $60 \mathrm{mg}$ doses in 1- to 11-year-old patients (Table 2) into the dexlansoprazole exposureresponse model developed using adult data, ${ }^{20}$ the intragastric $\mathrm{pH}$ values in the 1- to 11-year-old patients can be predicted. For the $30 \mathrm{mg}$ dose, the mean AUC value in pediatric patients was similar to the mean AUC values observed following a $30 \mathrm{mg}$ dose in adolescent or adult patients (Table 3). The exposure-response model predicted that the mean AUC for the $30 \mathrm{mg}$ dose in pediatric patients would 
A

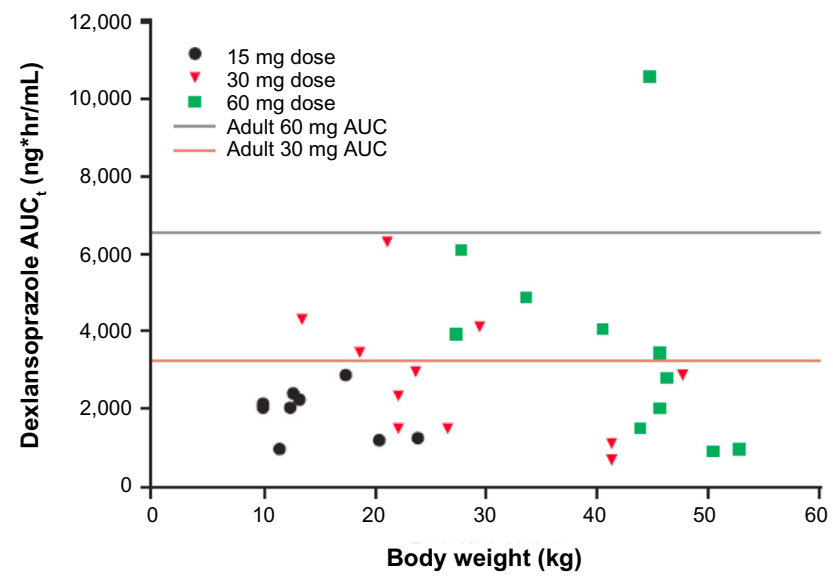

B

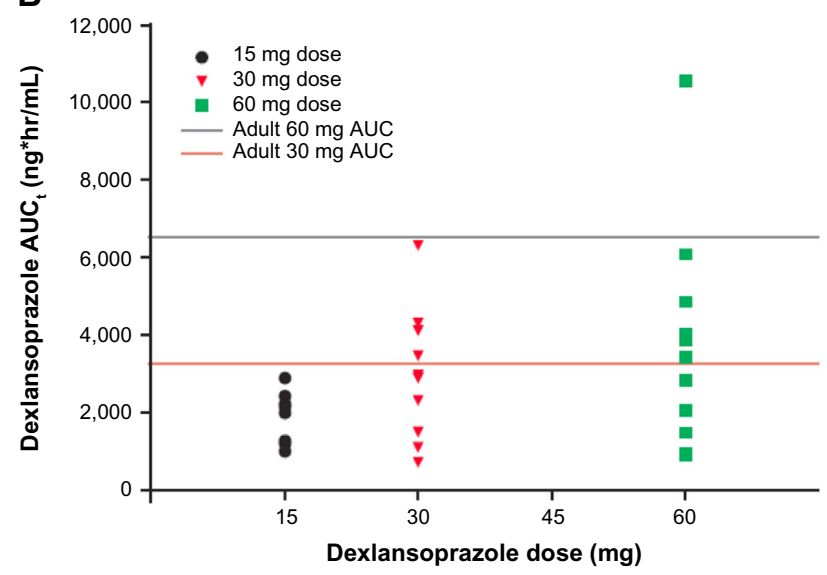

Figure 2 Individual dexlansoprazole $\mathrm{AUC}_{t}$ values versus (A) body weight and (B) dose on day 7 following once-daily administration of $15 \mathrm{mg}, 30 \mathrm{mg}$, or $60 \mathrm{mg}$ dexlansoprazole MR capsules to patients I to II years of age for 7 days.

Note: Adult mean AUC values were $3,275 \mathrm{ng} \cdot \mathrm{hr} / \mathrm{mL}$ for the $30 \mathrm{mg}$ dose and $6,529 \mathrm{ng} \cdot \mathrm{hr} / \mathrm{mL}$ for the $60 \mathrm{mg}$ dose. ${ }^{13}$

Abbreviations: $A \cup C$, area under the plasma concentration-time curve; $\mathrm{AUC}_{\mathrm{t}^{\prime}}$ area under the plasma concentration-time curve from time 0 to the time of the last quantifiable concentration; MR, modified release.

result in $\mathrm{pH}$ control, expressed as percent time $\mathrm{pH}>4$, of approximately $58.1 \%$ compared with $59.4 \%$ in adults. For the $60 \mathrm{mg}$ dose, the mean AUC value for pediatric patients was $73 \%$ of the adolescent mean and $57 \%$ of the adult mean AUC values. Although the mean AUC value for the $60 \mathrm{mg}$ dose in pediatric patients was lower than that observed in adults, the results of the exposure-response predictions indicate that the mean dexlansoprazole AUC value attained from the $60 \mathrm{mg}$ dose in 1 to 11 year olds would result in percent time $\mathrm{pH}>4$ of approximately $61 \%$ compared with $65 \%$ in adults. Overall, the data suggest that in the 1 - to 11-year-old population, administration of dexlansoprazole MR $30 \mathrm{mg}$ and $60 \mathrm{mg}$ would result in a substantial increase in intragastric $\mathrm{pH}$.

Once-daily dexlansoprazole MR $15 \mathrm{mg}, 30 \mathrm{mg}$, or $60 \mathrm{mg}$ for 7 days was well tolerated in the pediatric population enrolled in the current study. The overall incidence of AEs was low and did not increase with increasing dose. The only events reported for two or more patients overall were gastrointestinal events of vomiting, abdominal pain, diarrhea, and nausea. No clinically significant change from baseline was observed in clinical laboratory values, physical examination findings, ECG results, or vital sign measurements. Increases in gastrin levels were expected following daily administration of PPIs, including dexlansoprazole, and gastrin levels generally return to baseline levels within 7 days postdose. ${ }^{27}$

In summary, pediatric patients 1 to 11 years old with symptomatic GERD treated once daily with dexlansoprazole MR for 7 days showed approximately dose-proportional increases in weight-adjusted dexlansoprazole $\mathrm{AUC}$ and $\mathrm{C}_{\max }$. For a given dose, dexlansoprazole exposure decreased with increasing body weight. Dexlansoprazole MR doses of $30 \mathrm{mg}$ and $60 \mathrm{mg}$ in pediatric patients weighing up to $30 \mathrm{~kg}$ provided mean AUC values similar to those observed for adolescents and adults at comparable doses. In pediatric patients weighing greater than $30 \mathrm{~kg}$, the mean AUC values following administration of dexlansoprazole MR $30 \mathrm{mg}$ or $60 \mathrm{mg}$ were lower than those observed in adolescents and adults; however, the observed mean AUC values were predicted to provide a pharmacodynamic response, as measured by the percent time $\mathrm{pH}>4$, similar to that observed in adults at the same doses. Daily administration of dexlansoprazole MR $15 \mathrm{mg}$ to $60 \mathrm{mg}$ for 7 days was well tolerated in this study population.

\section{Acknowledgments}

Funding for this study was provided by Takeda Development Center Americas, Inc.

Medical writing assistance was provided by Jacqueline $\mathrm{Wu}, \mathrm{PhD}$ (Ledell Inc.), with funding provided by Takeda Pharmaceuticals International, Inc. The authors wish to acknowledge and thank the participating Principal Investigators at the three sites, who oversaw procedures and cared for the patients in this study: Robert Kane III, MD, Children's Mercy Hospital, Kansas City, MO (Pediatric Gastroenterology); Dennis S Riff, MD, FACG, Advanced Clinical Research Institute, Anaheim, CA (Gastroenterology); and Michael Spigarelli, MD, PhD, Cincinnati Children's Hospital, Cincinnati, OH (Pediatrics).

\section{Author contributions}

MCP and MK contributed to the conception and design of the study. MK and SN contributed to the acquisition and interpretation of the data. SN performed the statistical 
analysis. MK, SN, and MCP contributed to the drafting and critical review of the article and approved the final version of the article prior to submission. All authors had access to the data and vouch for the veracity and completeness of the data and the data analysis.

\section{Disclosure}

All authors are employees of the sponsor, Takeda Development Center Americas, Inc. The authors report no other conflicts of interest.

\section{References}

1. Orlando RC. The pathogenesis of gastroesophageal reflux disease: the relationship between epithelial defense, dysmotility, and acid exposure. Am J Gastroenterol. 1997;92(Suppl 4):3S-5S; discussion 5S-7S.

2. Nelson SP, Chen EH, Syniar GM, Christoffel KK. Prevalence of symptoms of gastroesophageal reflux during childhood: a pediatric practice-based survey. Pediatric Practice Research Group. Arch Pediatr Adolesc Med. 2000;154(2):150-154.

3. Gilger MA, El-Serag HB, Gold BD, et al. Prevalence of endoscopic findings of erosive esophagitis in children: a population-based study. J Pediatr Gastroenterol Nutr. 2008;47(2):141-146.

4. Cezard JP. Managing gastro-oesophageal reflux disease in children. Digestion. 2004;69 Suppl 1:3-8.

5. Vandenplas Y, Rudolph CD, Di Lorenzo C, et al. Pediatric gastroesophageal reflux clinical practice guidelines: Joint recommendations of the North American Society for Pediatric Gastroenterology, Hepatology, and Nutrition (NASPGHAN) and the European Society for Pediatric Gastroenterology, Hepatology, and Nutrition (ESPGHAN). $J$ Pediatr Gastroenterol Nutr. 2009;49(4):498-547.

6. El-Serag HB, Gilger M, Kuebeler M, Rabeneck L. Extraesophageal associations of gastroesophageal reflux disease in children without neurologic defects. Gastroenterology. 2001;121(6):1294-1299.

7. Gold BD, Gunasekaran T, Tolia V, et al. Safety and symptom improvement with esomeprazole in adolescents with gastroesophageal reflux disease. J Pediatr Gastroenterol Nutr. 2007;45(5):520-529.

8. Tolia V, Bishop PR, Tsou VM, Gremse D, Soffer EF, Comer GM; Members of the 322 Study Group. Multicenter, randomized, doubleblind study comparing 10,20 and $40 \mathrm{mg}$ pantoprazole in children (5-11 years) with symptomatic gastroesophageal reflux disease. J Pediatr Gastroenterol Nutr. 2006;42(4):384-391.

9. Fiedorek S, Tolia V, Gold BD, et al. Efficacy and safety of lansoprazole in adolescents with symptomatic erosive and non-erosive gastroesophageal reflux disease. J Pediatr Gastroenterol Nutr. 2005;40(3):319-327.

10. Hassall E, Israel D, Shepherd R, et al. Omeprazole for treatment of chronic erosive esophagitis in children: a multicenter study of efficacy, safety, tolerability and dose requirements. International Pediatric Omeprazole Study Group. J Pediatr. 2000;137(6):800-807.

11. Tolia V, Ferry G, Gunasekaran T, Huang B, Keith R, Book L. Efficacy of lansoprazole in the treatment of gastroesophageal reflux disease in children. J Pediatr Gastroenterol Nutr. 2002;35 Suppl 4:S308-S318.

12. Tolia V, Fitzgerald J, Hassall E, Huang B, Pilmer B, Kane R. Safety of lansoprazole in the treatment of gastroesophageal reflux disease in children. J Pediatr Gastroenterol Nutr. 2002;35 Suppl 4:S300-S307.
13. DEXILANT (dexlansoprazole) delayed-release capsules [prescribing information]. Deerfield, IL: Takeda Pharmaceuticals America, Inc.; 2013. Available from: www.takeda.us/products/default.aspx. Accessed September 29, 2014.

14. Peura DA, Metz DC, Dabholkar AH, Paris MM, Yu P, Atkinson SN. Safety profile of dexlansoprazole MR, a proton pump inhibitor with a novel dual delayed release formulation: global clinical trial experience. Aliment Pharmacol Ther. 2009;30(10):1010-1021.

15. Kukulka M, Wu J, Perez MC. Pharmacokinetics and safety of dexlansoprazole MR in adolescents with symptomatic GERD. J Pediatr Gastroenterol Nutr. 2012;54(1):41-47.

16. Gremse D, Winter H, Tolia V, et al. Pharmacokinetics and pharmacodynamics of lansoprazole in children with gastroesophageal reflux disease. J Pediatr Gastroenterol Nutr. 2002;35 Suppl 4:S319-S326.

17. Kuczmarski RJ, Ogden CL, Guo SS, et al. 2000 CDC Growth Charts for the United States: methods and development. Vital Health Stat. 2002;(246): 1-190.

18. World Medical Association. WMA Declaration of Helsinki - Ethical Principles for Medical Research Involving Human Subjects. FerneyVoltaire, France: World Medical Associatin; amended October 2013. Available from: http://www.wma.net/en/30publications/10policies/ b3/index.html.pdf?print-media-type \&footer-right=[page]/[toPage] . Accessed September 29, 2014.

19. International Conference on Harmonisation of Technical Requirements for Registration of Pharmaceuticals for Human Use. ICH Harmonised Tripartite Guideline - Guideline for Good Clinical Practice. Geneva, Switzerland: revised 10 June 1996. Availabe from: http://www.ich.org/ fileadmin/Public_Web_Site/ICH_Products/Guidelines/Efficacy/E6/ E6_R1_Guideline.pdf. Accessed September 29, 2014.

20. Vakily M, Zhang W, Wu J, Atkinson SN, Mulford D. Pharmacokinetics and pharmacodynamics of a known active PPI with a novel Dual Delayed Release technology, dexlansoprazole MR: a combined analysis of randomized controlled clinical trials. Curr Med Res Opin. 2009;25(3): 627-638.

21. Lee P, Rudolph C. Gastroesophageal reflux in infants and children. $A d v$ Pediatr. 2001;48:301-329.

22. Zannikos PN, Doose DR, Leitz GJ, et al. Pharmacokinetics and tolerability of rabeprazole in children 1 to 11 years old with gastroesophageal reflux disease. J Pediatr Gastroenterol Nutr. 2011;52(6):691-701.

23. Lind T, Rydberg L, Kylebäck A, et al. Esomeprazole provides improved acid control vs omeprazole In patients with symptoms of gastrooesophageal reflux disease. Aliment Pharmacol Ther. 2000;14(7): 861-867.

24. Hunt RH, Armstrong D, James C, et al. Effect on intragastric pH of a PPI with a prolonged plasma half-life: comparison between tenatoprazole and esomeprazole on the duration of acid suppression in healthy male volunteers. Am J Gastroenterol. 2005;100(9):1949-1956.

25. Gunasekaran T, Gupta S, Gremse D, et al. Lansoprazole in adolescents with gastroesophageal reflux disease: pharmacokinetics, pharmacodynamics, symptom relief efficacy, and tolerability. J Pediatr Gastroenterol Nutr. 2002;35 Suppl 4:S327-S335.

26. PREVACID ${ }^{\circledR}$ (lansoprazole) delayed-release capsules, PREVACID ${ }^{\circledR}$ SoluTab (lansoprazole) delayed-release orally disintegrating tablets [prescribing information]. Deerfield, IL: Takeda Pharmaceuticals America, Inc.; 2012. Available from: www.takeda.us/products/default. aspx. Accessed September 29, 2014.

27. Zhang W, Wu J, Atkinson SN. Effects of dexlansoprazole MR, a novel dual delayed release formulation of a proton pump inhibitor, on plasma gastrin levels in healthy subjects. $J$ Clin Pharmacol. 2009;49(4):444-454. 


\section{Publish your work in this journal}

Clinical and Experimental Gastroenterology is an international, peerreviewed, open access journal, publishing all aspects of gastroenterology in the clinic and laboratory, including: Pathology, pathophysiology of gastrointestinal disease; Investigation and treatment of gastointestinal disease; Pharmacology of drugs used in the alimentary tract;
Immunology/genetics/genomics related to gastrointestinal disease. This journal is indexed on CAS. The manuscript management system is completely online and includes a very quick and fair peer-review system. Visit http://www.dovepress.com/testimonials.php to read real quotes from published authors.

Submit your manuscript here: http://www.dovepress.com/clinical-and-experimental-gastroenterology-journal 